Pesq. Vet. Bras. 38(3):393-399, março 2018

\title{
Isolation and molecular characterization of Arcobacter butzleri and Arcobacter cryaerophilus from the pork production chain in Brazil ${ }^{1}$
}

\author{
Débora D.S. Gobbi², Maria G. Spindola ${ }^{2}$, Luisa Z. Moreno², Carlos E.C. Matajira²,
} Maria G.X. Oliveira², Renata Paixão ${ }^{2}$, Thais S.P. Ferreira ${ }^{2}$ and Andrea M. Moreno ${ }^{2 *}$

\begin{abstract}
Gobbi D.D.S., Spindola M.G., Moreno L.Z., Matajira C.E.C., Oliveira M.G.X., Paixão R., Ferreira T.S.P. \& Moreno A.M. 2018. Isolation and molecular characterization of Arcobacter butzleri and Arcobacter cryaerophilus from the pork production chain in Brazil. Pesquisa Veterinária Brasileira 38(3):393-399. Laboratório de Sanidade Suína e Virologia, Faculdade de Medicina Veterinária e Zootecnia, Universidade de São Paulo, Cidade Universitária, Avenida Prof. Dr. Orlando Marques de Paiva 87, São Paulo, SP 05508-270, Brazil. E-mail: morenoam@usp.br

Arcobacter is an emerging zoonotic pathogen, and the major transmission routes to humans are the handling or consumption of contaminated raw/undercooked food products of animal origin, water and seafood. The isolation and identification of Arcobacter species are not routine in clinical laboratories; therefore, its true incidence in human infections may be underestimated. The present study aimed to isolate and characterize Arcobacter from carcasses and fecal samples collected at swine slaughterhouses and from meat markets in São Paulo State, Brazil. The isolates were identified using multiplex-PCR to differentiate the species and analyzed by single-enzyme amplified fragment length polymorphism (SE-AFLP). Arcobacter spp. were isolated from $73.0 \%$ of swine carcasses, $4 \%$ of fecal samples and $10 \%$ of pork samples. A. butzleri was the most prevalent species identified, followed by $A$. cryaerophilus. Interestingly, the carcasses presented higher frequency of $A$. butzleri isolation, whereas only $A$. cryaerophilus was isolated from fecal samples. SE-AFLP enabled the characterization of $A$. butzleri and A. cryaerophilus into 51 and 63 profiles, respectively. The great genetic heterogeneity observed for both species corroborates previous reports. This study confirms the necessity for a standard isolation protocol and the improvement of molecular tools to further elucidate Arcobacter epidemiology.
\end{abstract}

INDEX TERMS: Arcobacter butzleri, Arcobacter cryaerophilus, swine, slaughterhouse, AFLP, bacterioses.

\section{RESUMO.- [Isolamento e caracterização molecular de Arcobacter butzleri e Arcobacter cryaerophilus de linhas de abate suíno e do comércio de carne no Brasil.] Arcobacter é um patógeno zoonótico emergente e as principais formas de transmissão para humanos são a manipulação e o consumo de água ou alimentos contaminados crus ou mal cozidos. $\mathrm{O}$ isolamento e a identificação das espécies de Arcobacter não fazem parte da rotina dos laboratórios}

\footnotetext{
${ }^{1}$ Received on April, 11, 2016.

Accepted for publication on December, 16, 2016.

${ }^{2}$ Laboratório de Sanidade Suína/Laboratório de Epidemiologia Molecular e Resistência a Antimicrobianos, Faculdade de Medicina Veterinária e Zootecnia, Universidade de São Paulo, Cidade Universitária, Avenida Prof. Dr. Orlando Marques de Paiva 87, São Paulo, SP 05508-270, Brazil. *Corresponding author: morenoam@usp.br
}

clínicos; dessa forma, a real incidência da infecção em humanos é subestimada. 0 presente estudo teve o objetivo de isolar e caracterizar Arcobacter de carcaças e amostras de fezes coletadas em dois abatedouros de suínos e de carne suína de dois açougues no Estado de São Paulo, Brasil. As estirpes foram identificadas utilizando multiplex-PCR para diferenciar as espécies e foram analisadas por polimorfismo no comprimento de fragmentos amplificados (SE-AFLP). Arcobacter spp. foi isolado de $73 \%$ das carcaças, $4 \%$ das amostras de fezes e de $10 \%$ das amostras de carne suína avaliadas. A. butzleri foi a espécie mais prevalente, seguida por A. cryaerophilus. As carcaças apresentaram a maior taxa de isolamento de $A$. butzleri enquanto que apenas A. cryaerophilus foi isolado das amostras de fezes. SE-AFLP possibilitou a caracterização de $A$. butzleri e A. cryaerophilus 
em 51 e 63 perfis de bandas, respectivamente. A grande heterogeneidade genética observada para ambas as espécies corrobora estudos previous. Estes resultados confirmam a necessidade de protocolos de isolamento padronizados e o aperfeiçoamento das ferramentas moleculares para aprofundar os conhecimetos sobre epidemiologia das infecções pelo gênero Arcobacter.

TERMOS DE INDEXAÇÃO: Arcobacter butzleri, Arcobacter cryaerophilus, suíno, abatedouro, AFLP, carne suína, bacterioses.

\section{INTRODUCTION}

The genus Arcobacter, previously named "aerotolerant Campylobacter," was discovered in 1991 (Vandamme et al. 1992). Presently, this genus comprises nineteen species: Arcobacter cryaerophilus, A. butzleri, A. nitrofigilis, A. skirrowii (Vandamme etal. 1992), A sulfidicus, (Wirsen etal. 2002), A. cibarius (Houf et al. 2005), A. halophilus (Donachie et al. 2005), A. mytili (Collado et al. 2009), A. thereius (Houf et al., 2009), A. marinus (Kim et al. 2010), A. trophiarium (De Smet et al. 2011), A. defluvii (Collado et al. 2011), A. molluscorum (Figueras et al. 2011a), A. ellisii (Figueras et al. 2011b), A. bivalviorum, A. venerupis (Levican et al. 2012), A. anaerophilus (Sasi Jyothsna et al. 2013), A. cloacae and A. suis (Levican et al. 2013).

A. butzleri is the most important and prevalent species of the genus and it has been classified as a serious hazard to human health by the International Commission on Microbiological Specifications for Foods (ICMSF 2002). Although the role of Arcobacter species in human diseases is not yet well established, A. butzleri and A. cryaerophilus have been associated with gastrointestinal diseases on several occasions in different countries, such as the United States, Italy, France, South Africa, England and Denmark (Collado \& Figueras, 2011), and they may lead to severe cases of bacteremia and death. Arcobacter infections in animals can be associated with multiple symptoms, including diarrhea, mastitis and abortion, although the bacteria may also be isolated from healthy carriers (Logan et al. 1982, Vandamme et al. 1992)

The most important route of Arcobacter transmission to humans is the ingestion of contaminated food and water (Hamill et al. 2008). Members of the Arcobacter genus are commonly present on food of animal origin with the highest prevalence occurring in poultry followed by pork and beef (Rivas et al. 2004). The contamination of meat products by Arcobacter is thought to primarily occur through direct fecal contamination of carcasses during the slaughtering process (Aydin et al. 2007).

The genotypic characterization of isolates can be performed with molecular techniques using restriction enzymes, such as pulsed field gel electrophoresis (PFGE), amplified fragment length polymorphism (AFLP) and restriction fragment length polymorphism (RFLP) (Hume et al. 2001, On et al. 2003). Few studies have been published regarding the epidemiology of Arcobacter in the pork production chain in Brazil. The purpose of the present study was to determine the occurrence of Arcobacter species in swine carcasses, feces and pork and to further characterize Arcobacter spp. isolates by single-enzyme amplified fragment length polymorphism (SE-AFLP).

\section{MATERIALS AND METHODS}

Sampling and microbiological analysis. The study was conducted on two slaughterhouses and two commercial establishments of refrigerated raw meat in São Paulo State, Brazil. The collections were performed monthly in each establishment during a period of five months. A total of 100 carcasses swabs, 100 samples of feces and 20 pork samples were analyzed. Carcass swabs were performed using sterile sponges (Whirl-Pak ${ }^{\circledR}$ Speci Sponge ${ }^{\circledR}$ bag - NASCO, EUA - 1-1/2" x 3" x 5/8") hydrated with $20 \mathrm{ml}$ of Letheen broth (Difco-BBL, Detroit, MI /USA). From each carcass, a $100 \mathrm{~cm}^{2}$ area of the ham, pelvis and foreleg and a $300 \mathrm{~cm}^{2}$ area of the chest (sternum region) were sampled. The samples were kept under refrigeration until laboratory processing.

A total of $225 \mathrm{~mL}$ of Johnson \& Murano broth (Johnson \& Murano 1999) was used for the incubation of carcasses swabs and $25 \mathrm{gr}$ of pork cuts while $2.5 \mathrm{gr}$ of feces were added to $22.5 \mathrm{~mL}$ of the same broth. The samples were incubated at $30^{\circ} \mathrm{C}$ for 48 hours. A $10 \mu \mathrm{L}$ aliquot of cultured broth was filtered into a $0.65 \mu \mathrm{m}$ cellulose sterile membrane and deposited over the selective agar, as previously described by Johnson \& Murano (1999) and incubated under aerobic conditions at $30^{\circ} \mathrm{C}$ for 48 hours. Suspected Arcobacter colonies (small, non-pigmented or grey) were transferred to a brain-heart infusion medium (BHI Difco-BBL, Detroit, MI, USA) and incubated at $30^{\circ} \mathrm{C}$ for 48 hours; up to three colonies were used per sample. The isolates were stored at $-86^{\circ} \mathrm{C}$ until processing.

Molecular identification. The isolates were grown on $5 \mathrm{~mL}$ of BHI (Difco-BBL, Detroit, MI, USA) for $48 \mathrm{~h}$ at $30^{\circ} \mathrm{C}$, and a sample of $200 \mu \mathrm{L}$ was used for DNA purification according to Boom et al. (1990) protocol. Species-specific primers were used for the Arcobacter molecular identification by multiplex PCR (Pentimalli et al. 2009).

PCR was performed in a $50 \mu \mathrm{L}$ reaction mixture containing $5 \mu \mathrm{L}$ of purified DNA, $1.5 \mathrm{mM} \mathrm{MgCl}, 10$ pmoles of each primer pair, 1.0 U of Taq DNA polymerase (Fermentas Inc., MA, USA), $1 \mathrm{X}$ PCR buffer and water. The reaction was conducted for 35 cycles comprising denaturation at $94^{\circ} \mathrm{C}$ for $1 \mathrm{~min}$, annealing for $1 \mathrm{~min}$ at $55^{\circ} \mathrm{C}$, and extension for $1 \mathrm{~min}$ at $72^{\circ} \mathrm{C}$. The amplified products were separated by electrophoresis in a $1.5 \%$ agarose gel and stained with BlueGreen ${ }^{\circledR}$ (LGC Biotecnologia, São Paulo, Brazil). The 100 bp DNA Ladder ${ }^{\circledR}$ (New England BioLabs Inc., Ipswich, MA/USA) was used for fragment size determination.

Single-enzyme amplified fragment length polymorphism (SE-AFLP). SE-AFLP was performed according to the protocol previously described by Mclauchlin et al. (2000). DNA band fragments were detected through electrophoresis at $24 \mathrm{~V}$ for $26 \mathrm{~h}$ in $2 \%$ agarose gel stained with BlueGreen ${ }^{\circledR}$ (LGC Biotecnologia, São Paulo, Brazil). The 100 bp DNA Ladder ${ }^{\circledR}$ (New England BioLabs Inc., Ipswich, MA/USA) was applied for molecular weight determinations. The fingerprint patterns were analyzed by a comprehensive pairwise comparison using Dice coefficient and the respective mean values were employed in UPGMA using BioNumeric 7.5 (Applied Maths NV, Sint-Martens-Latem, Belgium) to construct dendrograms. A $90 \%$ similarity value cut-off was used for the SE-AFLP cluster analysis (Van Belkum et al. 2007). The discriminatory index was calculated as described by Hunter \& Gaston (1988). 


\section{RESULTS}

From the 100 sampled carcasses, $73 \%$ were positive for Arcobacter spp. The fecal and pork samples presented a lower isolation rate, $4 \%$ and $10 \%$, respectively. Tables 1 and 2 present the isolation rates according to the sample origin and the identified Arcobacter species. From the positive carcasses, 202 strains were obtained and identified as A. butzleri (56.4\%) and $A$. cryaerophilus (43.6\%). Of the carcasses, $83.6 \%$ were positive for only one species while the remaining 16.4\% presented both $A$. butzleri and A. cryaerophilus.

From the fecal samples, 12 strains were obtained and identified as $A$. cryaerophilus, whereas only three strains were isolated from the pork samples with two characterized as $A$. butzleri and one as $A$. cryaerophilus. In summary, 217 Arcobacter strains were studied, of which 116 were characterized as A. butzleri and 101 were identified as A. cryaerophilus by the multiplex PCR.

All 217 strains were typeable by SE-AFLP. Dendrograms were constructed according to the species; Figure 1 presents the SE-AFLP patterns for A. butzleri, and Figure 2 presents them for A. cryaerophilus. SE-AFLP enabled the characterization of A. butzleri into 17 main clusters (C1 - C17), with over $75 \%$ of genetic similarity, and into further 51 genotypes (Fig.1). The A. cryaerophilus strains presented 63 SE-AFLP profiles grouped into 20 main clusters (C1 - C20), with over $75 \%$ of genetic similarity (Fig.2). The discriminatory index for A. butzleri was 0.97 , while $A$. cryaerophilus resulted in 0.99 . Despite the high genetic variation of the studied isolates, no correlation between the Arcobacter genotypes and the epidemiological data was observed.

\section{DISCUSSION}

In the present study, Arcobacter spp. were recovered from swine carcasses, feces, and pork samples. A high isolation rate was observed among the studied carcasses (73\%), differing from the results of Oliveira et al. (1999) in which $30.8 \%$ of carcass positivity for $A$. butzleri was found in southern Brazil. The results of the present study are similar to Van Driessche \&

Table 1. Isolation rates of Arcobacter spp. according to their origin

\begin{tabular}{cccc}
\hline Isolation site & Slaughterhouse 1 & Slaughterhouse 2 & Total \\
\hline Carcass & $82 \%(41 / 50)$ & $64 \%(32 / 50)$ & $73 \%(73 / 100)$ \\
Feces & $4 \%(2 / 50)$ & $4 \%(2 / 50)$ & $4 \%(4 / 100)$ \\
\hline Isolation site & Market 1 & Market 2 & Total \\
\hline Pork & $10 \%(1 / 10)$ & $10 \%(1 / 10)$ & $10 \%(2 / 20)$
\end{tabular}

Houf (2007) findings of an Arcobacter isolation rate of $91 \%$ in swine carcasses in Belgium.

The difference between the isolation rates can be related to the samples origin and the isolation protocols. Thus far, several methods have been described for Arcobacter isolation; however, none has been adopted as the standard. In the present study, the Johnson and Murano Broth was chosen because it is simple to prepare and it enables cultivation under aerobic conditions. In addition to the isolation methodology, other factors could explain the difference in the results, such as the geographic and climatic conditions, the animal age and sanitary status of the herds and the possibility of cross-contamination of the carcasses during the slaughter and/or animal transportation.

The lower isolation rates in swine feces and pork corroborates previous reports. Hume et al. (2001) and Kabeya et al. (2004) isolated Arcobacter spp. in less than 10\% of the analyzed fecal samples. Van Driessche et al. (2004) and Patyal et al. 2010 reported isolation rates above 20\% for swine feces using distinct isolation methodologies. A similar situation was observed with the pork isolation rates. Zanetti et al. (1996) and Kabeya et al. (2004) reported less than 10\% of the studied pork samples to be contaminated with Arcobacter spp. in accordance to this study result, whereas Ohlendorf \& Murano (2002) reported 32\% of the pork to be contaminated in the United States. Once more, the isolation protocols may be essential for the difference between the results; however, the age of the sampled animals and the intermittent bacterial elimination can also influence the feces isolation rates (Hume et al. 2001), and the cross-contamination of meat with the market environment can elevate the frequency of pork contamination.

The high frequency of $A$. butzleri among the isolated strains corroborates previous reports that describe it as one the most frequent species found in animal products and the carcasses of poultry and swine (Phillips 1999). Nevertheless, both A. butzleri and $A$. cryaerophilus are considered important pathogens due to their association with human and animal diseases. The isolation of both species from the same samples has also been previously reported (Van Driessche \& Houf 2007, Patyal et al. 2011). The absence of isolation of other Arcobacter species, such as A. skirrowii or A. cibarius, also corroborates the literature and could be due to their low sensibility to the applied culture mediums (Atanassova et al. 2008). According to Houf et al. (2003) and Van Driessche et al. (2004), the use of enrichment medium favors $A$. butzleri growth and could explain the disappearance of other species during the cultivation in selective media.

Table 2. Arcobacter species distribution among selected strains according to their origin

\begin{tabular}{|c|c|c|c|c|}
\hline Isolation site & Species & Slaughterhouse 1 & Slaughterhouse 2 & Total \\
\hline \multirow[t]{2}{*}{ Carcass } & A. butzleri & $55 \%(65 / 118)$ & $58.3 \%(49 / 84)$ & $56.4 \%(114 / 202)$ \\
\hline & A. cryaerophilus & $45 \%(53 / 118)$ & $41.6 \%(35 / 84)$ & $43.5 \%(88 / 202)$ \\
\hline \multirow[t]{2}{*}{ Feces } & A. butzleri & $0(0 / 0)$ & $0(0 / 0)$ & $0(0 / 0)$ \\
\hline & A. cryaerophilus & $100 \%(6 / 6)$ & $100 \%(6 / 6)$ & $100 \%(12 / 12)$ \\
\hline Isolation site & Species & Market 1 & Market 2 & Total \\
\hline \multirow[t]{2}{*}{ Pork } & A. butzleri & $0(0 / 0)$ & $100 \%(2 / 2)$ & $100 \%(2 / 2)$ \\
\hline & A. cryaerophilus & $100 \%(1 / 1)$ & $0(0 / 0)$ & $100 \%(1 / 1)$ \\
\hline
\end{tabular}




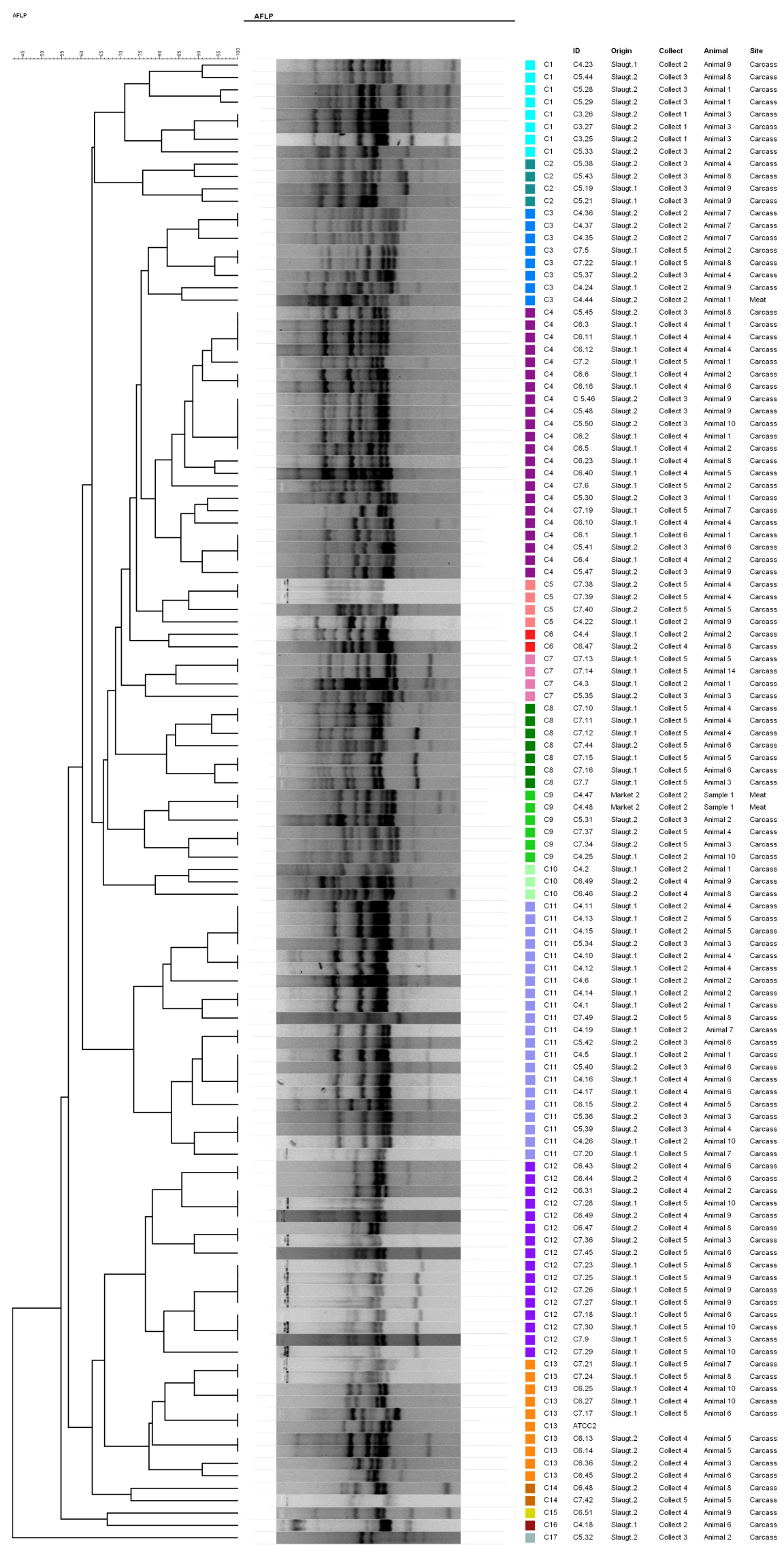

Fig.1. Dendrogram showing the comparison of Arcobacter butzleri strains through SE-AFLP (C1-17, Clusters obtained are identified in different colors). 


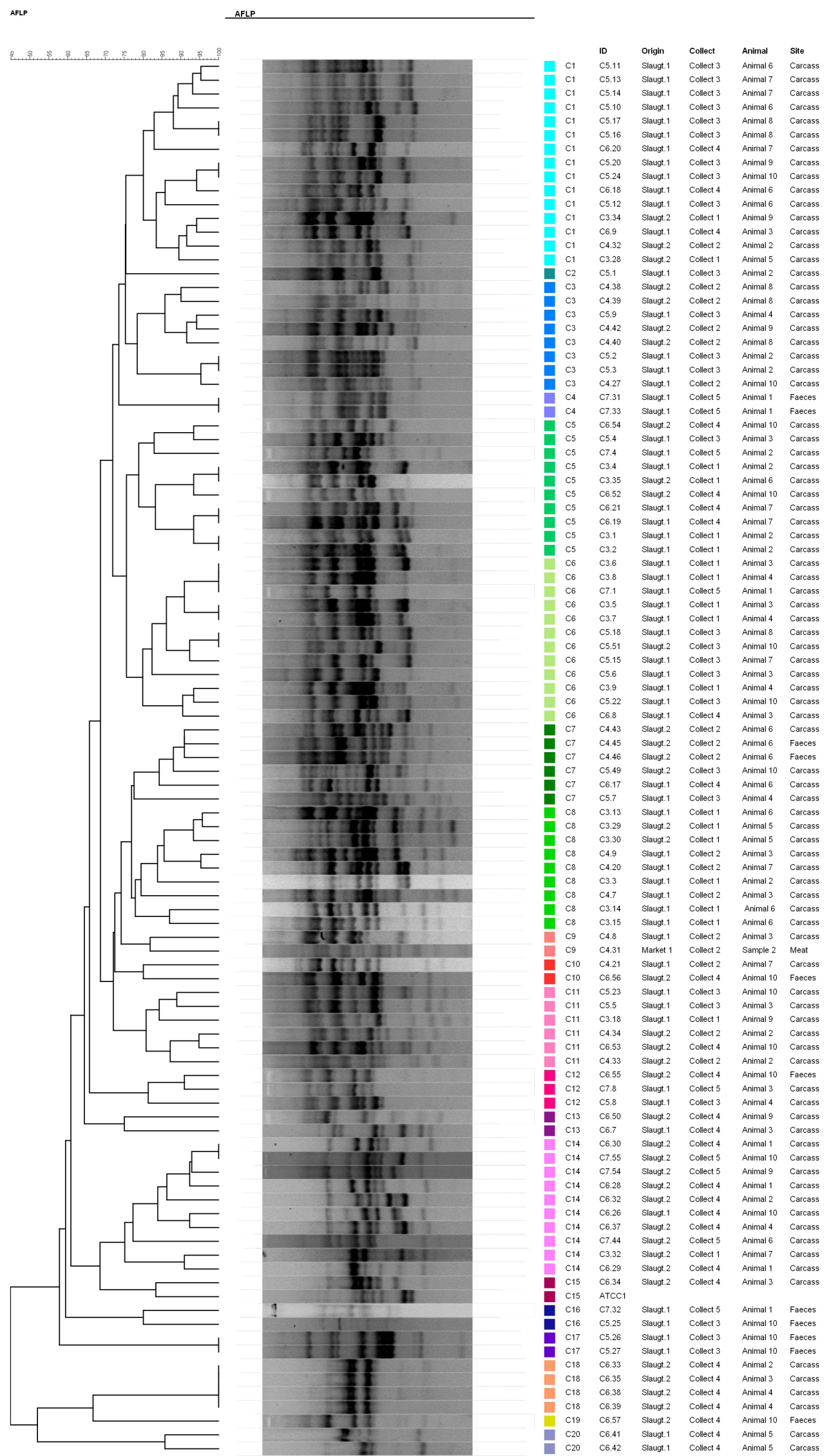

Fig.2. Dendrogram showing the comparison of Arcobacter cryaerophilus strains through SE-AFLP (C1-20, Clusters obtained are identified in different colors). 
Interestingly, the carcasses presented higher $A$. butzleri isolation, whereas only $A$. cryaerophilus was obtained from the fecal samples. The great heterogeneity of $A$. butzleri from carcasses favors the hypothesis of multiple contamination sources; moreover, the A. butzleri SE-AFLP patterns do not persist throughout the processing lines, or even into pork samples, reinforcing the possibility of multiple contamination sources prior to the processing lines. It has already been suggested that the cross-contamination by animals from different origins in the same slaughterhouse and processing line could explain Arcobacter broad genotypic variation (Ho et al. 2008).

A. cryaerophilus also presented high genotypic heterogeneity with discriminatory index higher than $A$. butzleri. The great heterogeneity of SE-AFLP patterns for both species corroborates previous reports (On et al. 2003, González et al. 2007), as well as the coexistence of genetically different isolates within the same animal has also been previously described (Ferreira et al. 2013). Considering the clusters obtained in both species studied is possible to observe that in each cluster, the strains from different slaughterhouses, collects, animals and sometimes different sites are grouped. Moreover, since the first description of the genus in 1992, the high heterogeneity of Arcobacter populations has been discussed with respect to the species and strain compositions (Ridley et al. 2008). It has been rationalized that the high genetic heterogeneity among Arcobacter isolates can be due to multiple contamination sources, the presence of multiple genotypes in a single animal and also a high degree of genomic recombination (Houf et al. 2002).

\section{CONCLUSIONS}

The variable results for carcass, feces and pork isolation rates and the large genotypic heterogeneity of Arcobacter isolates hamper the establishment of a food contamination route and prophylactic manners to avoid human and animal infection.

A standard isolation protocol, including possibly more than one technique for specific sites, is required.

Together with the improvement of molecular tools, it will be possible in the future to further elucidate Arcobacter epidemiology.

Acknowledgements.- This study was supported by FAPESP - Fundação de Amparo a Pesquisa do Estado de São Paulo (grants 2007/01636-5, 2010/13650-5 and 2010/17043-6) and CAPES - Coordenação de Aperfeiçoamento de Pessoal de Nível Superior.

\section{REFERENCES}

Atanassova V., Kessen V., Reich F. \& Klein G. 2008. Incidence of Arcobacter spp. in poultry: quantitative and qualitative analysis and PCR differentiation. J. Food Prot. 71(12):2533-2536. http://dx.doi.org/10.4315/0362028X-71.12.2533. PMid:19244910.

Aydin F., Gümüşsoy K.S., Atabay H.I., Iça T. \& Abay S. 2007. Prevalence and distribution of Arcobacter species in various sources in turkey and molecular analysis of isolated strains by ERIC-PCR. J. Appl. Microbiol. 103(1):27-35. http://dx.doi.org/10.1111/j.1365-2672.2006.03240.x. PMid:17584450.

Boom R., Sol C.J., Salimans M.M., Jansen C.L., Wertheim-van Dillen P.M. \& Van der Noordaa J. 1990. Rapid and simple method for purification of nucleic acids. J. Clin. Microbiol. 28(3):495-503. PMid:1691208.
Collado L. \& Figueras M.J. 2011. Taxonomy, epidemiology, and clinical relevance of the genus Arcobacter. Clin. Microbiol. Rev. 24(1):174-192. http://dx.doi. org/10.1128/CMR.00034-10. PMid:21233511.

Collado L., Cleenwerck I., Van Trappen S., De Vos P. \& Figueras M.J. 2009. Arcobacter mytili sp. nov., an indoxyl acetate-hydrolysis-negative bacterium isolated from mussels. Int. J. Syst. Evol. Microbiol. 59(Pt 6):1391-1396. http://dx.doi.org/10.1099/ijs.0.003749-0. PMid:19502322.

Collado L., Levican A., Perez J. \& Figueras M.J. 2011. Arcobacter defluvii sp. nov., isolated from sewage samples. Int. J. Syst. Evol. Microbiol. 61(Pt 9):21552161. http://dx.doi.org/10.1099/ijs.0.025668-0. PMid:20889767.

De Smet S., Vandamme P., De Zutter L., On S.L., Douidah L. \& Houf K. 2011. Arcobacter trophiarum sp. nov., isolated from fattening pigs. Int. J. Syst. Evol. Microbiol. 61(Pt 2):356-361. http://dx.doi.org/10.1099/ijs.0.022665-0. PMid:20305065.

Donachie S.P., Bowman J.P., On S.L. \& Alam M. 2005. Arcobacter halophilus sp. nov., the first obligate halophile in the genus Arcobacter. Int. J. Syst. Evol. Microbiol. 55(Pt 3):1271-1277. http://dx.doi.org/10.1099/ijs.0.63581-0. PMid:15879267.

Ferreira S., Fraqueza M.J., Queiroz J.A., Domingues F.C. \& Oleastro M. 2013. Genetic diversity, antibiotic resistance and biofilm-forming ability of Arcobacter butzleri isolated from poultry and environmental from a Portuguese slaughterhouse. Int. J. Food Microbiol. 162(1):82-88. http:// dx.doi.org/10.1016/j.ijfoodmicro.2013.01.003. PMid:23369730.

Figueras M.J., Collado L., Levican A., Perez J., Solsona M.J. \& Yustes C. 2011a. Arcobacter molluscorum sp. nov., a new species isolated from shellfish. Syst. Appl. Microbiol. 34(2):105-109. http://dx.doi.org/10.1016/j. syapm.2010.10.001. PMid:21185143.

Figueras M.J., Levican A., Collado L., Inza M.I. \& Yustes C. 2011b. Arcobacter ellisii sp. nov., isolated from mussels. Syst. Appl. Microbiol. 34(6):414-418. http://dx.doi.org/10.1016/j.syapm.2011.04.004. PMid:21723060.

González A., Ferrús M.A., González R. \& Hernández J. 2007. Molecular fingerprinting of Campylobacter and Arcobacter isolated from chicken and water. Int. Microbiol. 10(2):85-90. PMid:17661285.

Hamill S., Neill S.D. \& Madden R.H. 2008. A comparison of media for the isolation of Arcobacter spp. from retail packs of beef. J. Food Prot. 71(4):850854. http://dx.doi.org/10.4315/0362-028X-71.4.850. PMid:18468046.

Ho H.T., Lipman L.J. \& Gaastra W. 2008. The introduction of Arcobacter spp. in poultry slaughterhouses. Int. J. Food Microbiol. 125(3):223-229. http:// dx.doi.org/10.1016/j.ijfoodmicro.2008.02.012. PMid:18579247.

Houf K., De Zutter L., Van Hoof J. \& Vandamme P. 2002. Assessment of the genetic diversity among arcobacters isolated from poultry products by using two PCR-based typing methods. Appl. Environ. Microbiol. 68(5):2172-2178. http://dx.doi.org/10.1128/AEM.68.5.2172-2178.2002. PMid:11976086.

Houf K., De Zutter L., Verbeke B., Van Hoof J. \& Vandamme P. 2003. Molecular characterization of Arcobacter isolates collected in a poultry slaughterhouse. J. Food Prot. 66(3):364-369. http://dx.doi.org/10.4315/0362-028X-66.3.364. PMid:12636286.

Houf K., On S.L., Coenye T., Debruyne L., De Smet S. \& Vandamme P. 2009. Arcobacter thereius sp. nov., isolated from pigs and ducks. Int. J. Syst. Evol. Microbiol. 59(Pt 10):2599-2604. http://dx.doi.org/10.1099/ijs.0.0066500. PMid:19622651.

Houf K., On S.L., Coenye T., Mast J., Van Hoof J. \& Vandamme P. 2005. Arcobacter cibarius sp. nov., isolated from broiler carcasses. Int. J. Syst. Evol. Microbiol. 55(Pt 2):713-717. http://dx.doi.org/10.1099/ijs.0.63103-0. PMid:15774649.

Hume M.E., Harvey R.B., Stanker L.H., Droleskey R.E., Poole T.L. \& Zhang H.B. 2001. Genotypic variation among Arcobacter isolates from a farrow-to-finish swine facility. J. Food Prot. 64(5):645-651. http://dx.doi.org/10.4315/0362028X-64.5.645. PMid:11347994.

Hunter P.R. \& Gaston M.A. 1988. Numerical index of discriminatory ability of typing systems: an application of Simpson's index of diversity. J. Clin. Microbiol. 26(11):2465-2466. PMid:3069867. 
ICMSF 2002. Microorganisms in Foods: microbiological testing in food safety management. International Commission on Microbiological Specifications for Foods. Kluwer Academic/Plenum, New York.

Johnson L.G. \& Murano E.A. 1999. Development of a new medium for the isolation of Arcobacter spp. J. Food Prot. 62(5):456-462. http://dx.doi. org/10.4315/0362-028X-62.5.456. PMid:10340664.

Kabeya H., Maruyama S., Morita Y., Ohsuga T., Ozawa S., Kobayashi Y., Abe M., Katsube Y. \& Mikami T. 2004. Prevalence of Arcobacter species in retail meats and antimicrobial susceptibility of the isolates in Japan. Int. J. Food Microbiol. 90(3):303-308. http://dx.doi.org/10.1016/S01681605(03)00322-2. PMid:14751685.

Kim H.M., Hwang C.Y. \& Cho B.C. 2010. Arcobacter marinus sp. nov. Int. J. Syst. Evol. Microbiol. 60(Pt 3):531-536. http://dx.doi.org/10.1099/ ijs.0.007740-0. PMid:19654359.

Levican A., Collado L. \& Figueras M.J. 2013. Arcobacter cloacae sp. nov. and Arcobacter suis sp. nov., two new species isolated from food and sewage. Syst. Appl. Microbiol. 36(1):22-27. http://dx.doi.org/10.1016/j. syapm.2012.11.003. PMid:23265195.

Levican A., Collado L., Aguilar C., Yustes C., Diéguez A.L., Romalde J.L. \& Figueras M.J. 2012. Arcobacter bivalviorum sp. nov. and Arcobacter venerupis sp. nov., new species isolated from shellfish. Syst. Appl. Microbiol. 35(3):133138. http://dx.doi.org/10.1016/j.syapm.2012.01.002. PMid:22401779.

Logan E.F., Neill S.D. \& Mackie D.P. 1982. Mastitis in dairy cows associated with an aerotolerant campylobacter. Vet. Rec. 110(10):229-230. http:// dx.doi.org/10.1136/vr.110.10.229. PMid:7080408.

McLauchlin J., Ripabelli G., Brett M.M. \& Threlfall E.J. 2000. Amplified fragment length polymorphism (AFLP) analysis of Clostridium perfringens for epidemiological typing. Int. J. Food Microbiol. 56(1):21-28. http://dx.doi. org/10.1016/S0168-1605(00)00227-0. PMid:10857923.

Ohlendorf D.S. \& Murano E.A. 2002. Prevalence of Arcobacter spp. in raw ground pork from several geographical regions according to various isolation methods. J. Food Prot. 65(11):1700-1705. http://dx.doi.org/10.4315/0362028X-65.11.1700. PMid:12430689.

Oliveira S.J., Wesley I.V., Baetz A.L., Harmon K.M., Kader I.I. \& Uzeda M. 1999. Arcobacter cryaerophilus and Arcobacter butzleri isolated from preputial fluid of boars and fattening pigs in Brazil. J. Vet. Diagn. Invest. 11(5):462464. http://dx.doi.org/10.1177/104063879901100513. PMid:12968762.

On S.L., Harrington C.S. \& Atabay H.I. 2003. Differentiation of Arcobacter species by numerical analysis of AFLP profiles and description of a novel Arcobacter from pig abortions and turkey faeces. J. Appl. Microbiol. 95(5):1096-1105. http://dx.doi.org/10.1046/j.1365-2672.2003.02100.x. PMid:14633039.

Patyal A., Rathore R.S., Mohan H.V., Dhama K. \& Kumar A. 2011. Prevalence of Arcobacter spp. In humans, animals, and food of animal origin including seafood from India. Transbound. Emerg. Dis. 58(5):402-410. http://dx.doi. org/10.1111/j.1865-1682.2011.01221.x. PMid:21477113.
Pentimalli D., Pegels N., Garcia T., Martin R. \& Gonzalez I. 2009. Specific PCR detection of Arcobacter butzleri, Arcobacter cryaerophilus, Arcobacter skirrowii, and Arcobacter cibarius in chicken meat. J. Food Prot. 72(7):14911495. http://dx.doi.org/10.4315/0362-028X-72.7.1491. PMid:19681276.

Phillips C.A. 1999. The effect of citric acid, lactic acid, sodium citrate and sodium lactate, alone and in combination with nisin, on the growth of Arcobacter butzleri. Lett. Appl. Microbiol. 29(6):424-428. http://dx.doi. org/10.1046/j.1472-765X.1999.00668.x. PMid:10664988.

Ridley A.M., Toszeghy M.J., Cawthraw S.A., Wassenaar T.M. \& Newell D.G. 2008. Genetic instability is associated with changes in the colonization potential of Campylobacter jejuni in the avian intestine. J. Appl. Microbiol. 105(1):95-104. http://dx.doi.org/10.1111/j.1365-2672.2008.03759.x. PMid:18298527.

Rivas L., Fegan N. \& Vanderlinde P. 2004. Isolation and characterization of Arcobacter butzleri from meat. Int. J. Food Microbiol. 91(1):31-41. http:// dx.doi.org/10.1016/S0168-1605(03)00328-3. PMid:14967558.

Sasi Jyothsna T.S., Rahul K., Ramaprasad E.V., Sasikala C. \& Ramana C.V. 2013. Arcobacter anaerophilus sp. nov., isolated from an estuarine sediment and emended description of the genus Arcobacter. Int. J. Syst. Evol. Microbiol. 63(Pt 12):4619-4625. http://dx.doi.org/10.1099/ijs.0.054155-0. PMid:23918794.

Van Belkum A., Tassios P.T., Dijkshoorn L., Haeggman S., Cookson B., Fry N.K., Fussing V., Green J., Feil E., Gerner-Smidt P., Brisse S. \& Struelens M. 2007. Guidelines for the validation and application of typing methods for use in bacterial epidemiology. European Society of Clinical Microbiology and Infectious Diseases (ESCMID) Study Group on Epidemiological Markers (ESGEM). Clin. Microbiol. Infect. 13(Suppl.3):1-46. http://dx.doi. org/10.1111/j.1469-0691.2007.01786.x. PMid:17716294.

Van Driessche E. \& Houf K. 2007. Discrepancy between the occurrence of Arcobacter in chickens and broiler carcass contamination. Poult. Sci. 86(4):744-751. http://dx.doi.org/10.1093/ps/86.4.744. PMid:17369548.

Van Driessche E., Houf K., Vangroenweghe F., Nollet N., De Zutter L., Vandamme P. \& Van Hoof J. 2004. Occurrence and strain diversity of Arcobacter species isolated from healthy Belgian pigs. Res. Microbiol. 155(8):662-666. http:// dx.doi.org/10.1016/j.resmic.2004.04.011. PMid:15380554.

Vandamme P., Pugina P., Benzi G., Van Etterijck R., Vlaes L., Kersters K., Butzler J.P., Lior H. \& Lauwers S. 1992. Outbreak of recurrent abdominal cramps associated with Arcobacter butzleri in an Italian school. J. Clin. Microbiol. 30(9):2335-2337. PMid:1400998.

Wirsen C.O., Sievert S.M., Cavanaugh C.M., Molyneaux S.J., Ahmad A., Taylor L.T., DeLong E.F. \& Taylor C.D. 2002. Characterization of an autotrophic sulfide-oxidizing marine Arcobacter sp. that produces filamentous sulfur. Appl. Environ. Microbiol. 68(1):316-325. http://dx.doi.org/10.1128/ AEM.68.1.316-325.2002. PMid:11772641.

Zanetti F., Varoli O., Stampi S. \& De Luca G. 1996. Prevalence of thermophilic Campylobacter and Arcobacter butzleri in food of animal origin. Int. J. Food Microbiol. 33(2/3):315-321. http://dx.doi.org/10.1016/01681605(96)01166-X. PMid:8930716. 